\title{
Consolidating Public Sector Reform through Policy Transfer in Korea: Global Diffusion and Local Control*
}

\author{
Sauk-Hee Park**
}

\begin{abstract}
In Korea, demands for economic and social democratization increased after 2000, as the country dealt with economic recession after the 1997 Asian financial crisis and with other problems resulting from mismanaged domestic policies. In response, the Korean state carried out unprecedented reform of the public sector to address these problems by streamlining state capacity. The primary objectives of this article are to understand Korean public sector reform together with its domestic political factors from a policy transfer perspective, and to suggest an alternate model for the reforms. The reforms, which took place during the Kim Dae-Jung and the Roh Mu-Hyun administrations, were consolidated through proactive policy transfer by politico-bureaucratic decisions in order to establish a new statecraft despite the global diffusion of policy trends. Investigation of its domestic political circumstances and historical context reveals that the reforms were not direct emulations of global norms, but rather an attempt to use a mixture of models to raise the quality of government.
\end{abstract}

Keywords: Korean public sector reform, reform consolidation, policy transfer, state capacity, neo-Weberian state

\section{INTRODUCTION}

Once it had achieved economic and social development (Caiden \& Kim, 1999; Johnson, 1999; Kohli, 1999), the Korean state pursued a range of neoliberal policy reforms in the 1980s and 1990s. However, due to increasing demands for economic and social democratization to follow political democratization, coupled with the unde-

\footnotetext{
* This work was supported by the 2011 Research Fund of the Catholic University of Korea.

** Sauk-Hee Park is an assistant professor in the Department of Public Administration at the Catholic University of Korea. His academic interests include government reform and stateowned enterprises. His work has been published in the International Journal of Policy Studies. Email: nice113@catholic.ac.kr.
}

Manuscript received September 17, 2012; out for review October 4, 2012; review completed December 4, 2012; accepted December 7, 2012.

The Korean Journal of Policy Studies, Vol. 27, No. 3 (2012), pp. 1-25.

(C) 2012 by the GSPA, Seoul National University 
sired outcomes of some mismanaged policies, the state continued to streamline the public sector after 2000. As states transform the ways in which they govern society, they are influenced by various ideologies (Rockman \& Hahm, 2011); Korean public sector reforms sought to improve a chaotic domestic situation with a new statecraft.

Korean reforms have in fact been affected by global policy trends as Korea has proactively undergirded globalization as a crucial policy agenda (Lee, 2000). However, its reform policies have been consciously adapted through politico-bureaucratic decisions in line with its internal circumstances rather than directly adopted from global norms. Accordingly, an alternate model for the Korean public sector reform can be established through investigation of its domestic political circumstances as well as its historical context, using the policy transfer approach. Nonetheless, scholars seem to either have kept silent on the nature of Korean public sector reforms, with some exceptions (e.g., D.-R. Kim, 2012; Kwon \& Kim, 2011), or to have focused on comparing them with global norms (e.g., Chang, Park, \& Yoo, 1998; Henderson, 1999; Weiss, 2000).

Some argue that the New Public Management (NPM) and the New Public Governance (NPG) models have been diffused as global governing norms across states by their eclectic feature (e.g. Hood, 1991, 2000; Rhodes, 1996, 2000a). This approach has rarely taken the domestic context of each state into consideration. Others, arguing that government reform has evolved differently in different states, advocate that it should not be linked simplistically to global norms but analyzed through deep examination of the policy transfer process in each state (e.g., Cheung, 2005; Common, 2001; Painter, 2001). According to this approach, public sector reform needs to be understood as the result of voluntary transfer, not the diffusion of global norms.

A few models, such as NPM and NPG, have been continuously asserted to describe and even prescribe government reform across states (e.g. Peters, 1996, 2000; Pierre \& Peters, 2000; Stoker, 2006). Alternative models — such as joined-up government and the neo-Weberian state-have also continued to be addressed apart from the global norms (e.g., 6, 2004; Kavanagh \& Richards, 2001; Newman, 2000; Pollitt, 2003; Pollitt \& Bouckaert, 2011; Richards, 2008). Nonetheless, a plethora of studies have explicitly or implicitly argued in a less critical manner that the public sector reforms of the East Asian states have rested on widespread global norms or should do so (e.g., Bowornwathana, 2000; Painter, 2006). As a result, alternate models applicable to their government reforms are less likely to have been proposed in spite of a number of studies of government reform.

The Korean state initiated reform in a variety of policy areas in line with the NPM and NPG models during the transformational period after 2000. The reforms seem to have been constrained and shaped by domestic factors that affected the diffusion of 
policy trends. Accordingly, government reforms should not be regarded as the simple adoption of global governing norms, but rather as the conscious adaptation of policies from other jurisdictions through politico-bureaucratic decisions. These decisions were apparently affected by historical lessons from some mismanaged policies of previous regimes, the difficult economic situation of the 2000s, and growing social discordance. Much attention in this article is thus devoted to articulating a model suitable for explaining the reforms through examination of domestic Korean circumstances.

\section{THE GLOBAL NORM APPROACH AND ALTERNATE MODELS OF GOVERNMENT REFORM}

\section{The Diffusion of the Global Norm Approach}

The so-called Washington Consensus includes 10 basic economic principles: fiscal discipline, public expenditure priorities, tax reform, financial liberalization, exchange rates reform, trade liberalization, foreign direct investment, privatization, deregulation, and property rights (Maxwell, 2005). This neoliberal view, proposed in the early 1990s, has diffused global governing norms across the world (Green, 1987; Ocampo, 2002; Weyland, 1998). In particular, the NPM model, which emphasizes professional management, performance-motivated administration, and marketization, has become widespread, along with neoliberal economics and business-type managerialism (e.g., Barzelay, 2002; Hood, 2000).

The NPG model (e.g., Huxham \& Vangen, 1996; Kickert, 1997; Stocker, 2006), on the other hand, reflects the so-called post-Washington Consensus, which proposes a new paradigm with eight aspects: devolving authority and providing flexibility; ensuring performance, control, and accountability; developing competition and choice; providing responsive service; improving human resources management; optimizing information technology; improving the quality of regulation; and strengthening steering functions at the center (OECD, 1995). This offers an alternate norm to the NPM, based on power dependency and rational choice. It assumes that networks can supplement and supplant markets and hierarchies, as new governance is "a challenge to governability because they [networks] become autonomous and resist central guidance" (Rhodes, 1996, p. 652).

Proponents of the NPM model have argued that it has the eclectic feature of infinite reprogrammability through an international dialogue on state design and administrative reform (Guillen, 1994; Lynn, 1998), although government reform is rarely executed in a one-size-fits-all way. The NPM emphasizes three core values-frugality, rectitude, 
and resilience (Hood, 1991, p. 15) —and involves moving public sector organizations down-grid, "reducing the extent to which discretionary power is limited by uniform and general rules of procedure," and down-group, "making the public sector less distinctive as a unit from the private sector" (Dunleavy \& Hood, 1994, p. 9). Yet, it has been called both too narrow and too broad to improve government accountability. Kettl (1997) questions the fitness of the NPM to political institutions for ensuring service of the public interest and government accountability; Terry (1998) criticizes a misperceived relationship between entrepreneurialism, neomanagerialism, and democratic governance; and Kaboolian (1998) refutes a positive relationship between the market-oriented public manager model and democratic governance.

In line with these critiques, discourses on the NPG as an alternate model have gradually increased. The NPG concept is ambiguous and addressed in many different dimensions, ${ }^{1}$ which makes it difficult to define clearly, but its proponents generally refer to it as the creation of a governing mechanism "which cannot be externally imposed but is the result of the interaction of a multiplicity of governing and influencing actors" (Stoker, 1998, p. 17). It stands for shifting "the balance of power in society from governments ... to private individuals and groups" (Alcantara, 1998, p. 108), and emphasizes centrifugal powers displacing government control (Pierre \& Peters, 2000, p. 77). Accordingly, it has been argued that the "heterarchy" of self-organizations among interdependent actors supplant rigid polarization between the anarchy of markets and the hierarchy of government (Jessop, 2000, p. 16).

\section{Misperceptions of the Global Norm Approach}

As debureaucratization, deconcentration, and decentralization based on global norms have been diffused, new policies have overhauled traditional governing systems (Caiden, 1988). Government reform has been recognized as a prerequisite in streamlining state capacity. However, the pendulum of reform across states seems to have been swinging in different directions between, on the one hand, privatization, deregulation,

1. Peters (1996) examines four emerging new-governance models: market mechanisms, deregulation, participation, and flexibility. Rhodes (1996, 2000a) explores seven definitions: corporate governance, NPM, good governance, international interdependence, socio-cybernetic systems, new political economy, and networks. Stoker (1998) defines five features: "a set of institutions and actors," "the blurring of boundaries," "power dependence," "selfgoverning networks," and "new tools of government." Hirst (2000) describes five versions: good governance, international interdependence, corporate governance, NPM, and networks; and Bevir and Rhodes (2003) distinguish four concepts: "intermediate institutions," "marketising public services," "reinventing the constitution," and "trust and negotiation." 
decentralization, and delegation, and, on the other hand, nationalization, coordination, centralization, and bureaucratization (Aucoin, 1990). As Pollitt (2002, pp. 289-290) puts it, "the splendid coat of many colours envisaged by some reformers - slim, fast, effective, decentralised, open, trusted government-still lies more in the realms of hope and imagination than in demonstrated and warranted reality."

Because it takes the global diffusion of governing norms as the main source of government reform, the global norm approach is unlikely to thoroughly explain reforms in individual states, with their different proactive roles and internal contexts. The diffusion of reform policies could be affected by at least six national characteristics: stage of development, cultural traditions, institutional features, available resources, degree of reform professionalization, and political will (Hesse, 1997 p. 121). Accordingly, it has been argued that the global norm approach is too biased to explain reforms in nonAnglo-Saxon states and too narrow to explain those in Anglo-Saxon states $(6,2004)$. Also, it has been argued that, as each state is different in terms of capacity, political institutions, and social structure, government reform does not always mean uniformity such as the end or decline of the state, and a panacea may not exist in government reform at all.

Above all, as government reform could be discussed in three different aspects - the transition of the source of state authority from formal powers toward political capabilities, the replacement of legal and constitutional powers with entrepreneurial skills and brokerage abilities, and transformation toward embedded autonomy in terms of the role of state (Pierre \& Peters, 2000, pp. 196-198) - it might show various patterns of adaptation and implementation from state to state (Grindle, 2004). In short, government reform, given that "traditions are contingent, constantly evolving, and necessarily embedded in a historical context" (Bevir \& Rhodes, 2003, p. 43), can not necessarily be accomplished through application of global norms.

\section{The Rise of the Policy Transfer Approach and the Emergence of Alternate Models}

In the globalization era, legislative, institutional, and administrative approximation has been taken as a prerequisite for developing a state (Stone, 1999, p. 52). This implies that recent government reforms could be to a large extent explained by the global norms. It remains doubtful, however, what exactly it is that has been emulated from other jurisdictions, and to what extent and in what ways domestic factors have affected reform policy formation. In this vein, the policy transfer approach has emerged to offer alternative explanations of government reform (e.g., Dolowitz \& Marsh, 2000; Rose, 1991). It argues that government reform in any given state should 
not be interpreted simplistically in terms of global norms but rather intensively analyzed through examination of that state's domestic factors.

Policy transfer focuses on strategic choices by domestic politico-bureaucratic actors resulting from dissatisfaction with policy and uncertainty about the cause of policy problems and the effects of previous policy decisions. Thus, it seems to be politically very sensitive, as "the value of lessons lies in [agencies'] power to bias policy choice" and "both agency and structural factors will condition the degree of transfer and the character of implementation" (Stone, 1999, p. 53-54). Also, reform can be led by different categories of actors and their associations-for example, elected officials, political parties, bureaucrats, and "epistemic communities" (Evans \& Davies, 1999, p. 366). Corresponding policies of a state have relied on a variety of national characteristics and have usually been selected through policy transfer where the state's internal context interacts with global factors. There is evidence for both convergence and divergence in reform policies (Bennett, 1997; Blyth, 1997; Cheung, 2005; Common, 2001; Knill, 1999).

Although similarities within a program are increasing across national boundaries, the political, social, and historical context of a state may constrain and shape the contents and directions of policy transfer. Accordingly, since the mid-1990s, alternate models distinct from those of the global norm approach have emerged from the policy transfer approach, which in general attributes the sources of reform to the actions and interactions of domestic political factors and places less emphasis on the influence of global norms. This approach could enable the articulation of alternate explanations of government reforms. In particular, two models, the neo-Weberian state (NWS) and joined-up government (JG), with different approaches to reform orientation, coordination mechanisms, and the roles of politicians and civil servants, may be of more significance. While NPM emphasizes market-type mechanisms and competitive contracts, and the NPG model stresses networks and partnerships between stakeholders, the JG and NWS models emphasize to a greater extent bureaucratic authority through a disciplined hierarchy and to a lesser extent some business-type measures.

The JG model argues in general that an increase in state capacity is necessary to enhance government accountability (Clark, 2002; Flynn, 1999; Moore \& Keen, 2007), and in particular that policy making should be "strategic, holistic, focused on outcomes and delivery, evidence-based, inclusive and clearly defined" (Kavanagh \& Richards, 2001, p. 8). It may emerge from four distinct motives: "to eliminate contradictions and tensions between policies, ... to make better use of resources, ... to improve the flow of good ideas and cooperation between stakeholders [and] to produce a more integrated or seamless set of services" (Pollitt, 2003, p. 35). Its hierarchical version, arguing that politico-administrative leadership is homogeneous, emphasizes a rather top-down 
style in policy making and strengthening central integration; and its negotiation version (Christensen \& Laegreid, 2007, p. 1061; Rhodes, 2000b) assumes heterogeneous relationships between the public apparatus and stakeholders, and emphasizes negotiative policy making and heterarchical governing systems. In short, it makes the criticism that unpredicted outcomes of the global governing norms undermined the quality of government and worsened problems of segmentalism.

The NWS model, depicted by Pollitt and Bouckaert (2011) as a vision of a modernized, efficient, citizen-friendly government, stresses the continuing but changing roles of the state. It asserts, focusing on reinforcing state capacity, that government should play a crucial role in governing society in a modernized way. Thus, it focuses on some Weberian elements: "the role of state as the main facilitator, the role of representative democracy, the role of administrative law suitably modernized, and a public service with a distinctive status and culture" (p. 118). In the meantime, it puts an emphasis on "neo" elements: "an external orientation from citizens, a professional culture, not market mechanisms, devices for consultation, the achievement of results rather than the correct following of procedure, and meeting the needs of citizen" (p.119). In short, although it shares some reform objectives with the NPM and NPG models-such as restraining public expenditures, establishing better-performing public services, and sharpening accountability and transparency - the NWS model interprets the roles of state fairly differently. Table 1 compares the global norm and policy transfer approaches to understanding government reform.

Table 1. Two Theoretical Approaches to Government Reform

\begin{tabular}{l|l|l}
\hline & \multicolumn{1}{|c|}{ Global norm approach } & \multicolumn{1}{c}{ Policy transfer approach } \\
\hline $\begin{array}{l}\text { Sources of } \\
\text { government reform }\end{array}$ & $\begin{array}{l}\text { Diffusion of global governing norms } \\
\text { with less domestic adaptation }\end{array}$ & $\begin{array}{l}\text { Domestic adaptation and modification, } \\
\text { by political decision, of diffused global norms }\end{array}$ \\
$\begin{array}{l}\text { Representative } \\
\text { models }\end{array}$ & $\begin{array}{l}\text { New Public Management } \\
\text { New Public Governance }\end{array}$ & $\begin{array}{l}\text { Joined-up government } \\
\text { Neo-Weberian state }\end{array}$ \\
\hline
\end{tabular}

\section{THE DOMESTIC CONTEXT FOR PUBLIC SECTOR REFORM IN KOREA DURING THE TRANSFORMATIONAL PERIOD}

Little attention seems to have been paid so far to the policy dynamics through which internal factors vs. global norms affected reforms in the Korean public sector. Along with historical lessons from some mismanaged policies of the previous regimes, the reforms during the transformational period, in which measures for social and economic democratization after the regime transition in 1998 were widely taken, 
were consolidated in a way that reinforced state capacity. Facing chaotic economic affairs and growing social discordance, the Korean state continued to consolidate the public sector reforms, which were seen as politically very significant for economic and social development.

\section{Historical Lessons from Mismanaged Policies}

From the 1980s until the early 1990s, neoconservative reform was widely undertaken on a number of economic and social issues, and from the mid-1990s, the reform was extended to the public sector, which took up more than one-third of the national economy.

During the Chun Doo-Hwan administration (1981-1988), excessive interventions by the state in the policy process were criticized as undermining economic performance. Thus, the government undertook neoconservative reforms to decrease state involvement in economic policies. First, for economic stabilization, it reduced expenditures for social and economic development as well as general administration, ${ }^{2}$ established wage controls, and controlled credit to the public and private sectors. Second, for extensive structural adjustment, it pursued industrial restructuring, ${ }^{3}$ financial reforms, and the liberalization of the domestic market. These caused "a growing disjuncture between political power and social support" because of tense policy divisions, "the alienation of middle strata," and "the self-induced loss of state capacity" (Moon, 1988).

The subsequent Roh Tae-Woo administration (1988-1993) continued to pursue economic liberalization. With the erosion of state power, described as amounting to

2. For instance, government subsides from the Grain Management Fund and the Fertilizer Account were reduced; over 30 government funds were either eliminated (for example, the Machinery Industry Promotion Fund and the Electronic Industry Promotion Fund) or transferred to state-owned financial institutions (for example, the National Investment Fund); public corporations were subject to tighter government scrutiny; and the wages of public servants were decreased or frozen (Moon, 1988).

3. After the Act for Monopoly Regulation and Fair Trade was enacted to reduce industrial concentration in 1981, the heavy and chemical industry was restructured; six problem sectors including automobiles and power-generating equipment were reorganized, and financial support was extended to a new range of strategic high-technology industries; the style of economic management was changed to indirect and nondiscretionary supports such as incentives for R\&D and HRD; and attention began to be paid to small and medium-sized firms committed to import substitution in the parts and components industries (Haggard and Moon, 1983, as cited in Moon, 1988). 
the privatization of the state, which might be considered an example of Weber's patrimonialism, the direct political role of big business conglomerates or chaebol increased to unprecedented levels; for instance, a party dominated by the Hyundai Group acquired 24 seats in the 14th National Assembly in the March 1992 election. Economic performance worsened during this administration; the trade balance fell from a credit of US\$9.548 billion in 1987 to a deficit of US\$8.827 billion in 1992; the price of real estate skyrocketed to an average of 2.3 times that of 1987; and consumer prices increased by 40 percent to 50 percent between 1991 and 1992 (G.-H. Yang, 1995).

State strength was further drastically decreased during the Kim Young-Sam administration (1993 to 1998). The consolidation of market capitalism and economic liberalization became a new government ideology. ${ }^{4}$ Moreover, reforms levied from international institutions were reinforced after Korea became affiliated with the Organization for Economic Co-operation and Development (OECD) in December 1996 (B.-K. $\mathrm{Kim}, 2000$, p. 63). Attempts were thus widely made to reduce state involvement in economic and social development, and further liberalization policy was extended to the public sector. For instance, with its Master Plan for the Privatization and Reorganization of Public Corporations, the government planned to privatize about 61 public corporations, which accounted for 46 percent of Korea's 133 public corporations, and 16 corporations were in effect fully or partly privatized through either transfer to private owners or asset sales, 13 in 1994 and three in 1995 (KIPF, 2009, p. 542). The neoliberal reforms, however, resulted in internal disharmony due to ill-established political and social institutions (e.g., Chang, 2000; Henderson, 1999; Lee, 2000; Wade, 1998).

\section{Economic and Social Problems}

As a capitalist developmental state, Korea had become a charismatic megafauna for state-led economic expansion through a strong corporatist coalition with businesses and middle strata for some three decades. After the late 1990s, it was so engulfed by economic and political challenges that demands for its institutional capacity arose to enhance the quality of government, albeit unpredictably and amorphously. It faced an economic recession, which persisted after the 1997 financial crisis, as well as growing political and social discordance. In these circumstances, the state continued to consolidate public sector reform to streamline policy capacity, although resistance emerged

4. Total Korean foreign investments were $\$ 1.26$ billion in 1993, $\$ 2.30$ billion in 1994, $\$ 3.07$ billion in 1995, and $\$ 4.13$ billion in 1996 . About 50 percent of that amount was held by manufacturing companies, usually making inexpensive cars or electronics and marketing them in developing countries (BOK, 1997). 
from its support bases. In response to the economic situation, measures for economic growth and distributional equity were widely taken by reinforcing state capacity; growing political and social discordance increased the necessity of state involvement in policy affairs as well.

According to Oh (1999, p. 213), when the economy went into a recession after the 1997 crisis, the number of bankrupt companies increased from 1,268 in March 1997 to 1,318 in April. For example, the Hanbo Group, the 14th-largest chaebol, collapsed after defaulting on a US\$6 billion bank loan in January 1997. The amount of defaulted loans in the first four months of 1997 rose by 50.6 percent compared with the same period in 1996; for example, some subsidiaries of the Jinro, Sammi, and Dainong Groups had failed to honor debts by April 1997. As a bankruptcy prevention pact among banks barely sustained the conglomerates, they shut down most of their weak subsidiaries.

The Bank of Korea lowered the bank reserve ratio and expanded the money supply. Loans of \$1.5 billion in February 1997 and \$1 billion in March were extended to domestic banks; and 21 banks were bailed out in June 1997 with emergency loans from the Bank of Korea. In these situations, the International Monetary Fund bailout package of December 1997 entailed a number of austerity measures for the financial, industrial, and public sectors, and the government announced an economic recovery package that aimed to lower interest rates, prevent corporate bankruptcies, accelerate employment by public work projects, and increase funds for the unemployed.

Although it escaped this crisis, Korea also suffered from economic recession during the 2000s. Employment conditions worsened, particularly after the Non-Regular Workers Act was amended in 2007; the number of temporary workers rose and the employment rate declined. In 2008, Korea's employment rate was 63.8 percent, while the OECD average was 66.7 percent; Korea's rate for ages 15 to 24 was 23.8 percent, while the OECD average was 43.2 percent; and Korea's rate for ages 25 to 54 was 74.2 percent, while the OECD average was 77.2 percent. In addition, the ratio of parttime workers to total employees increased from 27.4 percent in 2002 to 35.5 percent in 2006, and the wage gap between full-time and part-time workers worsened from 32.9 percent in 2002 to 37.2 percent in 2006 (KNSO, 2007). Income inequality was also exacerbated: the Gini coefficient rose from 0.25 in 1990 to 0.320 in 2009 and 0.315 in 2010; and the relative poverty rate roughly doubled from 7.8 percent in 1990 to 14.9 percent in 2010 (Joong-Ang daily, 2011).

Many small- and medium-sized enterprises suffered from financial difficulties and a shortage of mechanical workers. The labor shortage rate among small- and mediumsized enterprises, as determined by the Small and Medium Business Agency, was recorded to be 6.5 percent in 2004 (Joong-Ang monthly, 2004). In contrast, the eco- 
nomic concentration of chaebols drastically increased: the economic concentration of the top 100 companies rose from 42.5 percent in 2003 to 51.1 percent in 2010 (HankukGyeongjae, 2012). Finally, real estate prices skyrocketed during this time, and household debt, of which mortgage loans made up about 43 percent in 2011, increased 7.4 percent in 2009 and 9.8 percent in 2010, although it had decreased gradually from 2006. The ratio of household debt to GDP in 2010 reached 81 percent, which was higher than the OECD average of 73 percent (KCCI, 2012).

Accordingly, the domestic markets went into economic recession despite the increase in exports, which was mainly led by big businesses. These economic difficulties ultimately resulted in social polarization and political discord. Labor disputes drastically increased, although the tripartite Presidential Committee of Labor, Business, and Government was established in 2000; and policy conflicts increased, for example over the reclamation of the Saemangeum tidal flats and the construction of Yeongwol Dam, the new administrative capital, and the Gyeongju radioactive waste disposal site.

\section{Political Consequences of Internal Circumstances}

These internal circumstances during the transformational period appeared to have political consequences and hence to affect the ways in which the Korean public sector reforms were formulated.

First, a growing disjuncture occurred between political democratization and economic and social democratization. Social discord-between regions, generations, genders, and classes - undermined the political legitimacy of the two newly installed democratic regimes and increased demands for economic and social democratization. Once political democratization was consolidated, demands for consolidation of economic and social democratization grew rapidly in a society that was divided by neoliberal reforms. Political institutions - the ruling party, the secretariat of the Blue House, and the career bureaucracy — were aligned with the rising demands.

Second, growing economic discord, whether it resulted from mismanagement of policies during previous regimes or global economic recession, dismantled support from political bases that were crucial for the two regimes-labor, students, and civil society. In addition, political support from the state's developmentalist coalition, businesses and the middle class, was weakened as their privileges were reduced by economic liberalization. Accordingly, it became the primary task of the two regimes to reinforce the political capacity of the state. The regimes sought to establish a new political coalition, composed of the middle class and civil society.

Third, the results of earlier mismanaged policies created disillusionment about globalization. Notably, the globalized economy, which the Korean state had pursued 
since the late 1980s, resulted in some negative outcomes. Thus, it became a crucial political agenda to overcome the malfunctions of the globalized economy with streamlined politico-bureaucratic institutions. Despite its globalization policy, the state pursued streamlining of political institutions in accordance with domestic circumstances. Consequently, globalization became both a policy goal to be attained and a policy problem to be remedied.

Finally, these domestic problems called for the self-reinforced capacity of the state. Stronger state capacity was needed in consolidating economic and social democratization, as was the case in other states. While pursuing social and economic democratization after political democratization, the Korean state might not put a priority on reducing the role of the government, but rather on streamlining its institutional capacity. Accordingly, public sector reform in Korea seemed to be guided by the goal of state transformation rather than state retreat.

\section{REINFORCING STATE CAPACITY BY CONSOLIDATING PUBLIC SECTOR REFORM IN KOREA}

Korean public sector reforms seem to have emulated reform policies in western democratic regimes from the outset. However, the reforms were constrained by internal circumstances and hence implemented in a fairly different way from global norms. With anomalous economic and social situations, and historical lessons drawn from previous regimes, the two regimes focused on consolidating the reforms to streamline state capacity to cope with a great number of policy issues. The Kim Dae-Jung regime, with a troika called the DJT (Kim Dae-Jung, Kim Jong-Phil, and Park TaeJoon) alliance, streamlined the public sector, including departments, public corporations, and executive agencies; the Roh Mu-Hyun regime continued to consolidate the reforms to enhance its institutional capacity, with support from its political coalition, which was gradually weakened but extensively supported by civil society.

\section{Public Sector Reform during the Kim Dae-Jung Administration}

Declaring four national reform agendas-public sector reform, reform of the business-labor relationship, financial sector reform, and social reform-the Kim Dae-Jung government took a variety of actions to transform the public sector, which was streamlined to enhance state capacity.

First, the government undertook three structural reforms. In the first reform, in February 1998, the Planning and Budget Committee and the Office of Budget were 
established under presidential authority, and the scope of the Ministry of Finance and Economy was reduced. The Administrative Coordination Office was upgraded to the Office of the Prime Minister to reinforce policy coordination. In the second reform, in May 1999, the Civil Service Commission was established. The third reform, in January 2001, was also devoted to improving policy capacity. Both the Minister for Finance and Economy and the Minister for Education and Human Resources were upgraded to a deputy prime ministers to increase economic policy coordination and to strengthen the re-education of displaced workers and human resource development, respectively (Choi, 1999; Jeong, Kim, Kim, \& Rinne, 2005).

Second, broad managerial reforms of departments were also undertaken (Jeong et al., 2005; Jung, 1999; P.-S. Kim, 2000). First, the government overhauled the personnel management system. Each department was supposed to lay off a certain portion of employees, and workforce numbers were strictly capped. As a result, the total number of civil servants (in the central, provincial, and local governments) was reduced from 934,000 at the end of 1997 to 868,000 at the end of 2001 (KNSO, 2011). Incentive schemes, promotion by results, and performance guidelines were adopted under a move to performance-based personnel management. Second, to raise budgetary efficiency, the Office of Budget introduced the Total Operational Expense System, under which each department was allowed to determine the priority and amount of its specific expenditures under a predetermined ceiling. In addition, budget incentive funds were allocated to departments in accordance with their achievements in budget management reform. Third, actions were taken to prevent corruption and improve transparency. The Presidential Advisory Council for Anti-Corruption was established in 1999; in 2002, it was upgraded to the Independent Anti-Corruption Commission.

Third, a range of managerial reforms were carried out in public corporations under the Public Corporations Act, amended in 1998. In each corporation, a committee was formed to recommend candidates for president; systems were adopted for making a management contract between the president and a minister of primary concern and for public announcements by management. The authority of the board of directors of each corporation was drastically increased. From 1999, each board had broad authority over the budget, business plans, personnel, payroll, and organizational management. For example, the system that nominated officials as members of the board was abolished; the board was composed of both executive and non-executive directors; people who had not served as internal staff were allowed to serve as executive director; and any director unlawfully causing a loss to the corporation was supposed to compensate for it. The system for assessing managerial performance was also thoroughly revised to promote performance-oriented and autonomous management.

The Prime Committee of Public Corporations' Affairs, which had the right to 
decide significant issues on the management of public corporations, was established under the Minister for Planning and Budget (KAPC, 2003). The committee had the ultimate authority to assess the management performance of public corporations and determine guidelines for budget formation and public announcements by management. In addition, it had the right to call for the dismissal of the president and executive directors of each corporation and to recommend candidates for non-executive directors and auditor to the Minister of Planning and Budget or ministers of primary concern. Also, in 2001, the Quasi-governmental Agencies Act was enacted to govern comprehensively about 100 quasi-governmental agencies, which had been ruled separately by different ministries.

Forth, fewer structural reforms of corporations were undertaken. According to the Plans for the Privatization and Restructuring of Public Corporations, asserted in July and August 1998, Korean Textbook Publication was fully privatized in 1998; Korean Technical Finance in 1999; Korean Oil Pipeline, Korean Steel, and Korean Heavy Industry in 2000; Korean Chemistry in 2001; Korean Tobacco \& Ginseng and Korean Telecom in 2002. And further, 20 son corporations out of a total of 61 were privatized or merged. In addition, under the 1999 Act for the Restructuring and Privatization of Public Corporations, Korean Electricity was partly privatized in 1999 and 2000, Korean Gas in 1999, and Korean Regional Heating Corporation in 2000.

Finally, in 1999, the government also introduced the Independent Executive Agency (IEA) system, in an initiative known as agencification and geared at increasing the managerial autonomy of executive agencies and preventing the state from governing them in bureaucratic ways. The Planning and Budget Committee, at the inception, selected 28 candidates for IEAs under 17 ministries and agencies, and 10 executive agencies were designated as IEAs at the beginning of 2000: the Central Public Relations Agency, Agency for Public Relations of National Defense, National Driving and Licensing Agency, National Science Museum, National Theatre, National Hospital, National Institute of Agricultural Engineering, two regional Agencies for the Maintenance of National Roads, and the National Maritime Corps Maintenance Agency (KIPA, 2007, pp. 19-20). The number of IEAs increased to 23 in 2001. Compared with other general executive agencies, IEAs were allowed more autonomy in organizational, personnel, and budgetary management, and performance contracts with ministers of primary concern and assessments were strengthened (KIPA, 2007, p. 15-18). 


\section{Public Sector Reform during the Roh Mu-Hyun Administration}

Reforms to streamline the public sector were further consolidated during the Roh Mu-Hyun administration (2003-2008). The ultimate goal of these reforms was to improve government accountability, not just to foster efficiency as in earlier administrations. The government undertook few structural reforms beyond what would normally occur under a new government, but rather continued to introduce managerial reforms to establish a more effective government (J.-S. Yang, 2004).

The Presidential Committee on Government Innovation and Decentralization was established to consolidate the reforms in 2003. Although it was created as an advisory board to the president, the Committee held substantial power. A number of other presidential committees were also established to deal with special policy issues and to raise the coordination ability of the Office of the President. A number of commissions and committees were established under the president and various ministers and agencies. In 2005 , there were 381 committees with 3,100 committee members under the central government, and 1,391 committees with 3,292 members under provincial governments. The budget for these committees increased from 54 billion Korean won in 2002 to 236.7 billion won in 2007 (Hwang, 2007).

Additionally, in 2005, the Minister for Science and Technology was upgraded to the third deputy prime minister in order to reinforce the state's science and technology competency, and the Ministry of Science and Technology became one of the comprehensive departments in the sector. New agencies were also established to meet various policy demands. As a result, the institution of the presidency was further reinforced by both the presidential secretariats and the authority of the comprehensive departments.

In regard to managerial reforms, organizational management reforms and budgetary reforms aimed at improving the effectiveness and service of government were continuously undertaken. Performance evaluation, incentive payments, and merit-based promotion were broadened; departments received somewhat more discretion for selfreorganization; and in 2007, the Planned Programming Budget System was introduced, both to raise the budgetary efficiency of the government and ultimately to enhance its budgetary autonomy and accountability. The government focused little on reducing its workforce, but rather undertook managerial reforms in an increasing number of departments. Consequently, the number of civil servants increased, from 890,000 in 2002 to 936,000 in 2004 and 975,000 in 2007 (K.-B. Kim, 2007; KIPA, 2007; Moon \& Ju, 2007).

The government also continued to reform public corporations and quasi-governmental agencies. The existing Public Corporations Act, the Act for the Restructuring and Privatization of Public Corporations, and the Quasi-governmental Agencies Act 
were abolished, and the Non-departmental Public Bodies (NDPBs) Act was enacted in 2006 to unify the systems that had governed NDPBs differently under the earlier three Acts, and to govern effectively a number of other NDPBs that had existed in blind spots of the public. 5 The new Act undertook to a greater extent managerial reforms such as reengineering, performance assessment, and customer-centered management, and to a lesser extent structural reforms such as privatization and restructuring.

Accordingly, some business-style management techniques-such as total quality management, management by objectives, and the balanced scorecard-were introduced in NDPBs to improve institutional capacity. Moreover, the management systems of NDPBs changed to enhance managerial autonomy and responsibility. For instance, guidelines for budget formation, organizational and personnel management, and business operations were deregulated; the public announcement, performance contract and assessment, and accounting systems were overhauled to enhance their accountability and transparency; the role of the board of directors of each NDPB and the authority of its president were reinforced; the procedure for nominating executive and non-executive directors was revised; and, in a few large NDPBs, a committee of audit and inspection was established to increase the power of internal auditing (KAPC, 2008, pp. 34-42).

The government also intensified the reform of executive agencies. The number of IEAs was increased to 45 in 2006, and the Korean Patent Agency and some regional offices of the Korean National Statistical Office were designated as IEAs in 2006 and 2007, respectively. The total number of officials working at IEAs was 4,973 in 2001 and increased to 9,857 , accounting for 1.68 percent of central government officials, in mid-2006 (KIPA, 2007, p. 15). The IEAs Act was amended six times to increase the scope and responsibilities of IEAs. At the end of 2004, IEAs were divided, based on their functions, into two types, administrative and business, with differentiated management systems. In contrast, the corporatization (decoupling from government) of some executive agencies was executed in a limited way. While the Korean Railways, which had been an executive agency, was vertically separated in 2006, and then corporatized to a public corporation and a quasi-governmental agency respectively, the Korea Post has remained as an executive agency, though attempts were made to corporatize it.

5. At the beginning of 2006, 14 public corporations were ruled by the Public Corporations Act, and about 100 quasi-governmental agencies were ruled by the Quasi-Governmental Agencies Act. However, the number of NDPBs ruled by the NDPBs Act reached 298 (24 public corporations, 77 quasi-governmental agencies, and 197 other NDPBs). 


\section{The Korean Path to Consolidating Public Sector Reform}

In public sector reform, the Korean state adapted and contextualized new policies diffused across states in accordance with its internal context. Certain policies, in contrast to widespread expectations, have been voluntarily absorbed through policy dynamics between domestic actors into Korea's particular socioeconomic and historical context. Thus, Korean public sector reform should be perceived, not as the adoption of global norms as a form of political and economic globalization, but rather as policy transfer constrained by internal circumstances. As a consequence, the reforms did not always cause a decline in state power, but sometimes led to streamlining state capacity to improve the quality of government. Constructing a new statecraft to cope with difficult economic and social situations seemed to be the foremost goal of the reforms. Thus, policy tools for the reforms have been selected in a variety of ways rather than a uniform way (cf. Börzel \& Risse, 2002; Jordan et al., 2005; Lascoumes \& Le Gales, 2007).

The Korean state, with its globalization policy, has continued to draw policy lessons from other jurisdictions in streamlining administrative systems since the 1990s. However, the momentum for transformation has been primarily domestic in origin, and hence reform policies have been initiated more for domestic reasons than because of international factors (Weiss, 2000). Thus, Korea has applied global norms to its domestic circumstances in a form of voluntary policy transfer that goes beyond policy convergence and takes into account economic and social conditions as well as lessons from previous regimes. Thus, the role of the state has not been significantly reduced by the reforms. On the contrary, the reforms have been consolidated in a way that reinforces state capacity, and have sometimes been selected in a mixed way on a continuum between two extremes.

It can be argued that the reforms have not been solely shaped by global norms but have also been proactively reformulated by politico-bureaucratic actors with a view to transforming, not diluting, the role of the state (c.f. Evans, 1997; Sørensen, 2004). Thus, Korea's public sector reforms, in line with Pollitt and Bouckaert (2011), cannot be completely explained by the NPM and NPG models, but also contain aspects of statecentric models such as NWS and JG. The state, despite rising demands for its retreat, continues to exercise a range of control mechanisms with more-or-less modernized

policy instruments. In sum, Korean government reform can be conceived as a mixture of policies on a complex map comprising three different models, as illustrated in figure 1 . 
Figure 1. Public Sector Reform in Korea

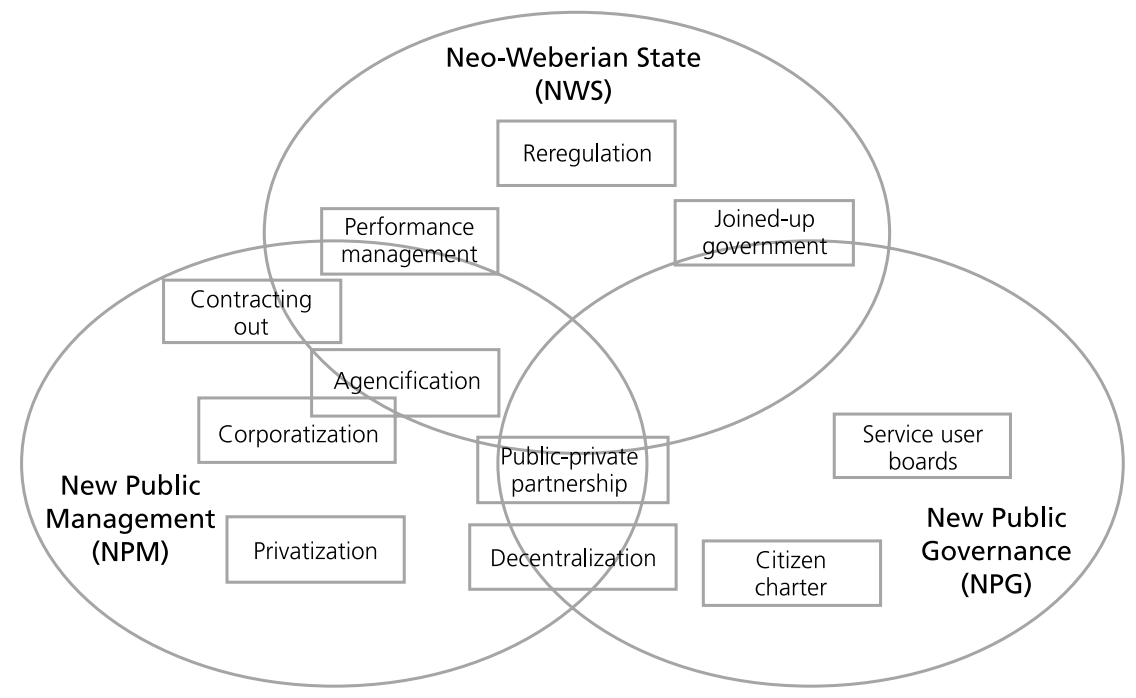

Source: adapted from Pollitt and Bouckaert (2011, p. 25).

\section{CONCLUSION}

The Korean state, facing a number of political, social, and economic challenges after the late 1990s, transformed the public sector beyond a traditional model to increase state capacity. With rising demands for economic and social democratization, the Kim Dae-Jung and Roh Mu-Hyun administrations undertook public sector reforms geared at streamlining the government during Korea's transformational period. The reforms did not solely aim to dilute the role of the state, but also to improve the quality of government to effectively cope with a range of policy problems resulting from some mismanaged policies of earlier regimes as well as difficult economic and social conditions. This suggests that the reforms were not directly emulated from global norms but rather formulated through voluntary policy transfer in which domestic political factors interacted with global ones.

Government reform across states could be interpreted by two different approaches, the global norm approach and the policy transfer approach. The global norm approach argues that the NPM or NPG model may be diffused as a global governing norm across national boundaries by their eclectic feature. However, this does not take the impact of each state's domestic context on its reforms sufficiently into consideration. By contrast, the policy transfer approach, by arguing that government reforms in 
different states do not necessarily evolve in uniform ways, advocates that they should not be simplistically linked to global norms but should be analyzed through intensive examination of internal circumstances. This approach could make theoretical use of alternate models, such as NWS or JG, to demystify Korean public sector reform.

In Korea, internal disharmony in the 1980s and 1990s arose from the problematic outcomes of some policies that were poorly established within a neoliberal paradigm. In addition, economic recession and social discordance persisting during the 2000 s had political consequences. First, a growing disjuncture occurred between political democratization and social and economic democratization. Political institutions were thus aligned with demands for social and economic democratization once political democratization was consolidated. Second, economic problems undermined the political legitimacy of the newly installed democratic regimes: support from the political bases of the regimes diminished; and support from the original developmentalist coalition was weakened as rewards to its members decreased. Third, as the results of earlier mismanaged policies created disillusion about globalization, overhauling the globalized economy with streamlined politico-bureaucratic institutions became a high priority. Finally, these domestic conditions created a need for the self-reinforced capacity of state. When consolidating economic democratization, the Korean state did not put a priority on reducing its role, but rather on streamlining its institutional capacity to enhance the quality of government.

Reform policies at the outset seemed to emulate those of western democratic regimes. The reforms were, however, in fact constrained by internal circumstances, and hence efforts to streamline the public sector (departments, public corporations, and executive agencies) diverged from global norms. The Kim Dae-Jung administration, with a troika called the DJT alliance, consolidated public sector reforms to raise its institutional capacity. The Roh Mu-Hyun administration also consolidated the reforms, with the support of its political coalition, which was gradually weakened but extensively supported by civil society. These reforms did not significantly reduce the role of the state but transformed it in ways that reinforced its capacity.

To sum up, public sector reforms carried out during Korea's transformational period seemed to be formulated through policy transfer and adapted, based on domestic political factors, from global governing norms. As a result, policy trends were not directly diffused to the state, but rather proactively transferred in keeping with Korea's political, social, and historical circumstances. Thus, in analyzing Korean public sector reform, it is important to examine both policy transfer and domestic circumstances. Korean government reform should not be understood as the internal adoption of global norms, but rather as policy transfer through politico-bureaucratic decisions aimed at creating a new statecraft. Accordingly, Korean public sector reforms might be seen as based on 
disillusion with globalization and consisting of a mixture of policies on a complex map comprising several alternate models.

\section{REFERENCES}

6, P [Perri 6]. 2004. Joined-up government in the western world in comparative perspective: A preliminary literature review and exploration. Journal of Public Administration Research and Theory, 14(1): 103-138.

Alcantara, C. H. 1998. Uses and abuses of the concept of governance. International Social Science Journal, 50(155): 105-113.

Aucoin, P. 1990. Administrative reform in public management: Programmes, principles, paradoxes and pendulums. Governance, 3(2): 115-137.

Barzelay, M. 2002. Origins of the New Public Management. In K. McLaughlin, S. P. Osborne, \& E. Ferlie (eds.). New Public Management: Current trends and future prospects (pp. 15-33). London: Routledge.

Bennett, C. J. 1997. Understanding ripple effects: The cross-national adoption of policy instruments for bureaucratic accountability. Governance, 10(3): 213-233.

Bevir, M., \& Rhodes, R. A. W. 2003. Searching for civil society: Changing patterns of governance in Britain. Public Administration, 81(1): 41-62.

Börzel, T. A., \& Risse, T. 2002. Public-private partnerships: Effective and legitimate tools of international governance? Retrieved October 28, 2011, from http://userpage .fu-berlin.de/ atasp/texte/021015_ppp_risse_boerzel.pdf.

Bowornwathana, B. 2000. Governance reform in Thailand: Questionable assumptions, uncertain outcomes. Governance: An International Journal of Policy and Administration, 13(3): 393-408.

Caiden, G. E. 1988. The vitality of administrative reform. International Review of Administrative Sciences, 54(3): 331-358.

Caiden, G. E., \& Kim, B-W. (eds.). 1999. A dragon's progress: Development administration in Korea. Connecticut: Kumarian Press.

Chang, H.-J. 2000. The hazard of moral hazard: Untangling the Asian crisis. World Development, 28(4): 775-788.

Chang, H.-J., Park, H.-J., \& Yoo, C. 1998. Interpreting the Korean crisis: Financial liberalisation, industrial policy and corporate governance. Cambridge Journal of Economics, 22(6): 735-746.

Cheung, A. B. L. 2005. The politics of administrative reforms in Asia: Paradigms and legacies, paths and diversities. Governance, 18(2): 257-282.

Choi, K. 1999. Public sector reform in Korea. Korea Focus, 7(5): 66-77. 
Christensen, T., \& Laegreid, P. 2007. The whole of government approach to public sector reform. Public Administration Review, 67(6): 1059-1065.

Clark, T. 2002. New labour's big idea: Joined-up government. Social Policy and Society, 1(2): 107-117.

Common, R. 2001. Public management and policy transfer in Southeast Asia. Aldershot, UK: Ashgate.

Dolowitz, D., \& Marsh, D. 2000. Learning from abroad: The role of policy transfer in contemporary policy-making. Governance, 13(1): 5-24.

Dunleavy, P., \& Hood, C. 1994. From old public administration to New Public Management. Public Money \& Management, 14(3): 9-16.

Evans, P. B. 1997. The eclipse of the state: Reflections on stateness in an era of globalization. World Politics, 50(1): 62-87.

Evans, M., \& Davies, J. 1999.Understanding policy transfer: A multi-level, multidisciplinary perspective. Public Administration, 77(2): 361-385.

Flynn, N. 1999. Modernising government in Britain. Parliamentary Affairs, 52(4): 582-597.

Green, D. G. 1987. The new right: The counter-revolution in political, economic and social thought. Brighton, UK: Wheatsheaf.

Grindle, M. S. 2004. Good enough governance: Poverty reduction and reform in developing countries. Governance: An International Journal of Policy, Administration, and Institutions, 17(4): 525-548.

Guillen, M. F. 1994. The age of eclecticism: Current organizational trends and the evolution of managerial models. Sloan Management Review, 36(1): 75-86.

Hankuk-Gyeongjae [Korean Economy]. 2012, June 21.

Henderson, J. 1999. Uneven crises: Institutional foundations of East Asian economic turmoil. Economy and Society, 28(3): 327-368.

Hesse, J. J. 1997. Rebuilding the state: Public sector reform in Central and Eastern Europe. In J. Lane (ed.), Public sector reform: Rationale, trends and problems. London: Sage Publications.

Hirst, P. 2000. Democracy and governance. In J. Pierre (ed.) Debating governance: Authority, steering, and democracy. Oxford: Oxford University Press.

Hood, C. 1991. A public management for all seasons? Public Administration, 69: 3-19.

Hood, C. 2000. The art of the state: Culture, rhetoric, and public management. Oxford: Oxford University Press.

Huxham, C., \& Vangen, S. 1996. Working together: Key themes in the management of relationships between public and non-profit organizations. International Journal of Public Sector Management, 9(7): 5-17.

Hwang, S.-Y. 2007. How to reduce the number of government committees [in Korean]. 
In J.-H. Kim (ed.), 2007 policy proposals (pp. 299-306). Seoul: Institute for Free Enterprises.

Jeong, H.-Y., Kim, D.-K., Kim, K.-H., \& Rinne, J. 2005. South Korea. In World Bank administrative and civil service reform: Country reform summaries. Washington, DC: World Bank. Retrieved April 14, 2012, from http://www.worldbank.org/ publicsector/civilservice/rsSouthKorea.pdf.

Jessop, B. 2000. Governance failure. In G. Stoker (ed.), The new politics of British local governance (pp. 11-32). Hampshire, UK: Macmillan Press.

Johnson, C. 1999. The developmental state: Odyssey of a concept. In M. Woo-Cumings (ed.), The developmental state (pp. 32-60). Ithaca, NY: Cornell University Press.

Jordan, A., Wurzel, R. K. W., and Zito, A. 2005. The rise of 'new' policy instruments in comparative perspective: Has governance eclipsed government? Political Studies, 53(3): 477-496.

Joong-Ang daily. 2011, October 26. p. E8.

Joong-Ang monthly. 2004, December.

Jung, Y.-D. 1999, April. Globalization, domestic political economy, and the institutional persistence of the developmental state in Korea. Paper presented at the IPSA Structure and Organization of Government Conference (The Impact of Globalization on Governance), University of Wisconsin, Madison.

Kaboolian, L. 1998. The New Public Management: Challenging the boundaries of the management vs. administration debate. Public Administration Review, 58(3): 189-193.

Kavanagh, D., \& Richards, D. 2001. Departmentalism and joined-up government: Back to the future. Parliamentary Affairs, 54(1): 1-18.

Kettl, D. F. 1997. The global revolution in public management: Driving themes, missing links. Journal of Policy Analysis and Management, 16(3): 446-462.

Kickert, W. J. M. 1997. Public governance in the Netherlands: An alternative to Anglo-American managerialism. Public Administration, 75(4): 731-752.

Kim, B.-K. 2000. Party politics in South Korea's democracy: The crisis of success. In L. Diamond \& B.-K. Kim (eds.), Consolidating democracy in South Korea. Boulder, CO: Lynne Rienner.

Kim, D.-R. 2012. The legacy of deferred compensation in Korea's administrative reforms. Korean Journal of Policy Studies, 27(2): 203-218.

Kim, K.-B. 2007, November. Government reform and vision for Korea's advanced government [in Korean]. Paper presented at the Conference of the Korean Advancement Policy, Seoul.

Kim, P.-S. 2000. Administrative reform in the Korean central government: A case study of the Dae Jung Kim's administration. Asian Review of Public Adminis- 
tration, 12(2): 81-95.

Knill, C. 1999. Explaining cross-national variance in administrative reform: Autonomous versus instrumental bureaucracies. Journal of Public Policy, 19(2): 113-139.

KAPC (Korean Association of Public Corporations). 2003. Assessment of the management system of public corporations of Korea [in Korean].

2008. The revisions of the management of public corporations [in Korean].

KCCI (Korea Chamber of Commerce and Industry). 2012. The current situation of household debts and policy tasks [in Korean].

KIPA (Korean Institute of Public Administration). 2007. Assessment of the organizational institutions of Korean government and tasks for their development: The independent executive agency system and team-based organization system [in Korean].

KIPF (Korea Institute of Public Finance). 2009. Policy tasks for the modernization of non-departmental public bodies [in Korean].

KNSO (Korean National Statistics Office). 2007. An additional survey of economic activity population.

KNSO (Korea National Statistical Office). 2011. Korea statistical yearbook: 20032010. Daejeon: Author.

Kohli, A. 1999. Where do high-growth political economies come from? The Japanese lineage of Korea's “developmental state.” In M. Woo-Cumings (ed.), The developmental state. Ithaca, NY: Cornell University Press.

Kwon, H.-J., \& Kim, E.-J. 2011. Transition from the developmental state: The deliberative policy process of civil service pension reform in Korea. Korean Journal of Policy Studies, 26(3): 91-111.

Lascoumes, P. and Le Gales, P. 2007. Understanding public policy through its instruments: From the nature of instruments to the sociology of public policy instrumentation. Governance, 20(1): 1-21.

Lee, Y.-H. 2000. The failure of the weak state in economic liberalization: Liberalization, democratization and the financial crisis in South Korea. Pacific Review, 13(1): 115-131.

Lynn Jr., L. E. 1998. The New Public Management: How to transform a theme into a legacy. Public Administration Review, 58(3): 231-237.

Maxwell, S. 2005 The Washington consensus is dead! Long live the meta-narrative! Overseas Development Institute Working Paper 243. London: Overseas Development Institute. Retrieved January 31, 2012, from http://www.odi.org .uk/resources/docs/ 2476.pdf.

Moon, C.-I. 1988. The demise of a developmental state? Neoconservative reforms and political consequences in South Korea. Journal of Developing Societies, 4. 
Moon, M.-J., \& Ju, K.-W. 2007. A comparative study on government size, scope of function and strength of government in the three administrations [in Korean]. Korean Journal of Public Administration, 45(3): 51-80.

Moore, J., \& Keen, J. 2007. Accounting for joined-up government: The case of intermediate care. Public Money and Management, 27(1): 61-68.

Newman, J. 2000. Beyond the New Public Management? Modernizing public service. In J. Clarke, S. Gewirtz, \& E. McLaughlin (eds.), New managerialism, new welfare? London: Thousand Oaks.

Ocampo, J. A. 2002. Rethinking the development agenda. Cambridge Journal of Economics, 26(3): 393-407.

OECD (Organisation for Economic Co-operation and Development). 1995. Governance in transition: Public management reforms in OECD countries. Paris: Author.

Oh, J. K.-C. 1999. Korean politics: The quest for democratization and economic development. Ithaca, NY: Cornell University Press.

Painter, M. 2001. The politics of administrative reform in East and Southeast Asia: From gridlock to continuous self-improvement? Governance, 17(3): 361-386.

Painter, M. 2006. Thaksinisation or managerialism? Reforming the Thai bureaucracy. Journal of Contemporary Asia, 36(1): 26-47.

Peters, B. G. 1996. The future of governing: Four emerging models. Lawrence: University of Kansas Press.

Peters, B. G. 2000. Governance and comparative politics. In J. Pierre (ed.), Debating governance: Authority, steering, and democracy. Oxford: Oxford University Press.

Pierre, J., \& Peters, B. G. 2000. Governance, politics and the state. Hampshire, UK: Macmillan.

Pollitt, C. 2002. The New Public Management in international perspective: An analysis of impacts and effects. In K. McLaughlin, S. P. Osborne, \& E. Ferlie (eds.), New Public Management: Current trends and future prospects (pp. 274-292). London: Routledge.

Pollitt, C. 2003. Joined-up government: A survey. Political Studies Review, 1(1): 34-49.

Pollitt, C., \& Bouckaert, G. 2011. Public management reform: A comparative analysis: New Public Management, governance and the neo-Weberian state (3rd ed.). Oxford: Oxford University Press.

Rhodes, R. A. W. 1996. The new governance: Governing without government. Political Studies, 44(4): 652-667.

Rhodes, R. A. W. 2000a. Governance and public administration. In J. Pierre (ed.), Debating governance: Authority, steering, and democracy. Oxford: Oxford University Press. 
Rhodes, R. A. W. 2000b. New labour's civil service: Summing-up joining-up. Political Quarterly, 71(2): 151-166.

Richards, D. 2008. New labour and the civil service: Reconstituting the Westminster model. Hampshire, UK: Palgrave Macmillan.

Rockman, B. A., \& Hahm, S.-D. 2011. The notion of good and bad governance in comparative perspective. Korean Journal of Policy Studies, 26(2): 1-16.

Rose, R. 1991. What is lesson drawing? Journal of Public Policy, 11(1): 3-30.

Sørensen, G. 2004. The transformation of the state: Beyond the myth of retreat. London: Palgrave Macmillan.

Stoker, G. 1998. Governance as theory: Five propositions. International Social Science Journal, 50(155): 17-28.

Stoker, G. 2006. Public value management: A new narrative for networked governance? American Review of Public Administration, 36(1): 41-57.

Stone, D. 1999. Learning lessons and transferring policy across time, space and disciplines. Politics, 19(1): 51-59.

Terry, L. D. 1998. Administrative leadership, neo-managerialism, and the public management movement. Public Administration Review, 58(3): 194-200.

Wade, R. 1998. The East Asian debt and development crisis of 1997-?: Causes and consequences. World Development. 26(8): 1535-1553.

Weiss, L 2000. Developmental states in transition: Adapting, dismantling, innovating, not "normalizing." Pacific Review, 13(1): 21-55.

Weyland, K. 1998. Swallowing the bitter pill: Sources of popular support for neoliberal reform in Latin America. Comparative Political Studies, 31(5): 539-568.

Yang, G.-H. 1995. Liberalisation and the political role of the chaebol in Korea: The rise and fall of the Unification National Party. In J. Cotton (ed.), Politics and policy in the new Korean state: From Roh Tae-Woo to Kim Young-Sam. New York: St. Martin's Press.

Yang, J.-S. 2004. Public sector reforms. In C. Harvie, H.-H. Lee, \& J.-G. Oh (eds.), The Korean economy: Post-crisis policies, issues and prospects (120-142). Cheltenham, UK: Edward Elgar. 